\title{
Positional effects in consonant clusters
}

\author{
Jongho Jun
}

1. Introduction

2. C2 dominance effect

3. Non-assimilatory neutralization

4. Evidence for the Cue-based approach

4.1 Neutralization sites $\neq$ syllable positions

4.2 Apical neutralization

5. Evidence for the Prosody-based approach

5.1 Obstruent-sonorant clusters in Catalan

5.2 Obstruent-sonorant clusters in Eastern Andalusian Spanish

6. Conclusion

\section{Introduction}

It is commonly observed across languages that phonological processes may apply only in certain ("nonprominent”) positions. In contrast, elements in other ("prominent”) positions typically resist or trigger these processes. Such prominent vs. non-prominent positional distinctions are further applicable to more general patterns of licensing and neutralization of phonological contrasts; namely, featural/segmental contrasts are likely to be licensed in prominent positions whereas these contrasts are likely to be neutralized in non-prominent positions. Pairs of prominent and non-prominent positions include wordinitial vs. non-initial, stressed vs. unstressed, root vs. affix and prevocalic vs. preconsonantal positions. Among the positional effects involving these pairs, this chapter is mainly concerned with those involving the two members of intervocalic consonant clusters. See Beckman (1998) and Barnes (2006) for recent extensive investigations of other positional effects; see also CHAPTER 112: ROOT-AFFIX ASYMMETRIES and CHAPTER 109: CATEGORY-SPECIFIC EFFECTS. In intervocalic C1C2 clusters, the preconsonantal C1 is more likely to undergo phonological processes such as voicing and place assimilation, in contrast with the prevocalic C2 which is rarely subject to such processes. I will refer to this asymmetric positional effect as the C2 dominance effect.

This chapter discusses empirical data patterns which display positional effects. Its focus will be on how to explain the $\mathrm{C} 2$ dominance effect. I will begin with a discussion of typical data patterns of the C2 
dominance effect and proceed to less common, somewhat exceptional, patterns which are nonetheless crucial in comparing the previous approaches. Specifically, I will concentrate on the comparison between Prosody-based (Ito 1986, 1989; Goldsmith 1990; Rubach 1990; Cho 1990; Lombardi 1995, 1999, 2001; Beckman 1998; Kabak \& Idsardi 2007) vs. Cue-based approaches (Steriade 1993, 1995, 1997/1999, 2001, 2009; Flemming 1995; Padgett 1995; Jun 1995, 2004; Hume 1999; Boersma 1998; Côté 2000; Wilson 2001; Blevins 2003; Seo 2003). It will be shown that current evidence from empirical data is mixed. Much of the commonly observed data, to be discussed in the following two sections, can be equally well accommodated by the two approaches. However, there exist relatively less common patterns which can be understood under the view of only one of the two approaches. Evidence exclusively supporting the Cuebased approach will be discussed in section 4, and evidence for the Prosody-based approach in section 5. 


\section{C2 dominance effect}

Assimilation occurs in consonant clusters when one of two neighboring consonants takes on some property of the other. I will call the former (i.e., the undergoer of assimilation) the target, and the latter (i.e., the source of the assimilating property) the trigger. With respect to the assimilation in C1C2 clusters, it is cross-linguistically true that $\mathrm{C} 1$ and $\mathrm{C} 2$ are the target and the trigger, respectively, and thus the direction of assimilation is regressive. To illustrate this C2 dominance effect, I will first consider patterns of voicing assimilation and then patterns of place assimilation. Finally, patterns of consonant deletion will be discussed.

As can be seen in (1), in Catalan, Polish, and Russian, voiced and voiceless obstruents are separate phonemes, and they may occur unhindered in prevocalic position. But, in clusters composed of obstruents, the first constituent of the cluster must agree in voicing with the following constituent. As shown in (1-i), underlyingly voiced obstruents in C1 become voiceless before a voiceless obstruent in C2 whereas underlyingly voiceless obstruents in C1 become voiced before a voiced obstruent in C2, as in (1-ii). Thus, voicing assimilation occurs in clusters, targeting C1. This C2 dominance effect in voicing assimilation can be seen in other languages including Dutch, Yiddish, Sanskrit, Romanian, Serbo-Croatian, Ukranian, Hungarian, Egyptian Arabic, and Lithuanian. Steriade (1997/1999) and Beckman (1998) provide an indepth discussion of voicing assimilation, i.e., a type of laryngeal neutralization, in these languages, emphasizing that it is normally regressive, and thus its C2 dominance effect is quite robust.

(1) Regressive voicing assimilation

a. Catalan (from Beckman 1998, citing Hualde 1992)

\begin{tabular}{|c|c|c|c|}
\hline & & & _ voiceles \\
\hline /b/ & Кóßə & 'wolf (f.)' & Kóppətît \\
\hline /g/ & әті́уә & 'friend (f.)' & әmíkpətít \\
\hline
\end{tabular}

\begin{tabular}{|c|c|c|c|}
\hline & & & __voiced \\
\hline$/ \mathrm{t} /$ & gátə & ‘cat (f.)’ & gáddulén \\
\hline$/ \mathrm{k} /$ & pókə & 'little (f.)' & pógdú \\
\hline
\end{tabular}

b. Polish (from Rubach 1996; Beckman 1998)

\begin{tabular}{|c|c|c|c|c|c|}
\hline \multirow{3}{*}{ i. } & \multirow{3}{*}{$\begin{array}{l}/ \mathrm{b} / \\
/ \mathrm{d} /\end{array}$} & \multirow{3}{*}{$\begin{array}{l}z ́ a[b] a \\
\text { wo[d]a }\end{array}$} & \multirow{3}{*}{$\begin{array}{l}\text { 'frog' } \\
\text { 'water' }\end{array}$} & \multicolumn{2}{|c|}{ __voiceless } \\
\hline & & & & źa[pk]a & 'small frog' \\
\hline & & & & wo[tk] $] \mathrm{a}$ & 'vodka' \\
\hline & & & & __voiced & \\
\hline ii & $/ \mathrm{t} \int /$ & li[t $]] y c ́$ & 'count' & $\mathrm{li}[\underline{\mathrm{dzb}}] \mathrm{a}$ & 'numeral' \\
\hline
\end{tabular}




$$
\text { /k/ szla[k]-u 'route, gen. sg.' szla[gb]ojowy 'war route' }
$$

c. Russian (from Kenstowicz 1994; Kiparsky 1985; Padgett 2002)

\begin{tabular}{|c|c|c|c|c|}
\hline \multirow[b]{2}{*}{ h/ } & \multirow[b]{2}{*}{ korob-a } & \multirow[b]{2}{*}{ 'bastbax, gen.sg.' } & \multicolumn{2}{|c|}{ _ voiceless } \\
\hline & & & kirop-ka & 'bastbax, dimin.' \\
\hline /d/ & pod-nesti & 'to bring (to)' & pot-pisat ${ }^{j}$ & ‘to sign’ \\
\hline & & & _ voiced & \\
\hline /s'/ & pros'-it' & 'to ask' & proz'-ba & 'request' \\
\hline$/ \mathrm{t} /$ & ot-jexat ${ }^{\mathrm{j}}$ & 'to ride off' & od-brosit ${ }^{j}$ & 'to throw aside' \\
\hline
\end{tabular}

Consonant place assimilation occurs in clusters when one of two adjacent consonants, i.e., the target, takes on the place of articulation of the other, i.e., the trigger. Consonants differ in the likelihood of being targeted in place assimilation depending on the manner and place of articulation. Nasals (as opposed to stops and continuants) and coronals (as opposed to labials and velars) are the most likely targets of place assimilation (Mohanan 1993; Jun 1995, 2004). For instance, as shown in (2i), in Diola-Fogny, only nasals can be targeted in place assimilation, and in Yakut, only coronals can be targeted. However, assimilation applies only when such potential target consonants occupy C1, not C2, position. Notice in (2a-ii) that nasals such as /m/ in C2 only trigger, not undergo, assimilation. In (2b-ii), coronals in C2 resist place assimilation.

(2) Regressive place assimilation

a. Diola Fogny (from Sapir 1965)
i. /ni+gam+gam/ [nigangam]
'I judge'
ii. /na+mi:n+mi:n/ [nami:mmi:n]
'he cut (with a knife)'

b. Yakut (from Krueger 1962)

i. Coronals in $\mathrm{C} 1$ are the target.

$\begin{array}{lll}/ \text { at+ka/ } & \text { [akka] } & \text { 'to a horse' } \\ \text { /ün+kür/ } & \text { [ünkür] } & \text { 'sloping, aslant' }\end{array}$

ii. Coronals in C2 are not the target.

$\begin{array}{lll}\text { /tobuk+ta/ } & \text { [tobukta }] & \text { 'knee, partitive case' } \\ \text { /silim+te/ } & \text { [silimne] } & \text { 'glue, partitive' }\end{array}$

As shown above, place assimilation is typically regressive, just as voicing assimilation is; and thus it targets $\mathrm{C} 1$, and its trigger is C2. This C2 dominance effect in place assimilation is very robust across languages, as shown in typological studies by Webb (1982), Mohanan (1993) and Jun (1995, 2004), and there are only a small number of exceptions. (See Jun (1995, 2004) and McCarthy (2008) for the 
discussion of such exceptional progressive assimilation patterns.) Optional patterns of place assimilation are not different from obligatory and categorical patterns in the preponderance of regressive assimilation over progressive assimilation. In Korean, the occurrence of place assimilation is subject to speech style and rate, thus is optional (Kim-Renaud 1974/1991; Jun 1996; Son, Kochetov \& Pouplier 2007; Son 2008; Kochetov \& Pouplier 2008). This optional assimilation is regressive. Specifically, only coronal and labial stops and nasals in C1 are the target, and non-coronals in C2 are the trigger, as can be seen in (3a-i). Notice in (3a-ii) that coronals in C2 do not undergo the assimilation, and non-coronals in C1 cannot trigger the assimilation (see CHAPTER 7: CORONALS). English casual speech assimilation is very much like Korean assimilation in the direction of assimilation and segmental characteristics of the target. The only difference is that only coronals, not labials, can be the target in English assimilation. Notice that coronals undergo assimilation only when they are in C1, not C2, as can be seen in (3b).

(3) Casual speech place assimilation

a. Korean ${ }^{1}$

$$
\begin{aligned}
& \text { i. } / \text { mit }+ \text { ko/ } \quad[\text { mitk'o] } \sim[\text { mikk'o] } \\
& \text { /ip + ko/ [ipk'o] [ikk'o] } \\
& \text { /cinan pam/ [cinanbam] [cinambam] 'last night' } \\
& \text { ii. /ik ta } / \text { [ikt'a], *[itt'a], *[ikk'a] } \\
& \text { /ip + ta/ [ipt’a], *[itt’a], *[ipp’a] } \\
& \text { /pan + pota/ [panbota], *[pambota], *[pangota] }
\end{aligned}
$$

b. English (based on Bailey 1970)
i. right poor
righ[p] poor
good-bye
goo[b]bye
ii. keep track *kee[t] track
*keep [p]rack
back track
*ba[t] track
*back [k]rack

This C2 dominance effect in casual speech assimilation can also be seen in other languages such as German (Kohler 1990, 1991a,b, 1992), Malay, Thai (Lodge 1986, 1992), Toba Batak (Hayes 1986), Spanish (Harris 1969) and Ponapean (Rehg \& Sohl 1981); see also CHAPTER 82: REDUCTION on assimilation as a casual speech phenomenon.

The C2 dominance effect is not limited to assimilation in consonant clusters, but extends to consonant deletion in clusters. Consonant deletion occurs in clusters when one of two adjacent consonants, i.e., the target, deletes. It has been observed and emphasized in the literature (Côté 2000; Wilson 2001; Jun 2002; McCarthy 2008) that C1, as opposed to C2, is always the target in such deletions. For instance,

\footnotetext{
${ }^{1}$ In Korean which has a three-way laryngeal contrast among obstruents, i.e., lenis, aspirated and tens, lenis obstruents become tense after an obstruent (Post-obstruent tensing), and voiced between sonorants (Inter-sonorant voicing). See KimRenaud (1986) and Ahn (1998) for details of these automatic processes.
} 
as shown in (4), stops in C1, not C2, delete in Diola Fogny, West Greenlandic and Basque.

(4) Consonant deletion: $\mathrm{C} 1$ is the target

a. Diola Fogny (Sapir 1965)

\begin{tabular}{|c|c|c|}
\hline$/ \mathrm{let}+\mathrm{ku}+\mathrm{jaw} /$ & [le kujaw] & 'they won't go' \\
\hline /kuteb sinayas/ & [kute sinanas] & 'they carried the food' \\
\hline /عket bo/ & [عke bo] & 'death there' \\
\hline
\end{tabular}

b. West Greenlandic (Rischel 1974; Fortescue 1980)

$\begin{array}{lll}\text { /qanik + lerpoq/ } & \text { [qani lerpoq] } & \text { 'begins to approach' } \\ \text { /ukijuq }+ \text { tuqaq/ } & \text { [ukiju tuqaq } & \text { 'old year' } \\ \text { /anguti }+ \text { kulak/ } & \text { [angu kulak] } & \text { 'he goat' }\end{array}$

c. Basque (Hualde 1987)

$\begin{array}{lll}\text { /bat + paratu/ } & \text { [ba-paratu] } & \text { 'put one' } \\ \text { /bat + kurri/ } & \text { [ba-kurri] } & \text { 'run one' } \\ \text { /guk + piztu/ } & \text { [gu-piztu] } & \text { 'we light' } \\ \text { /guk + kendu/ } & \text { [gu-kendu] } & \text { 'we take away' }\end{array}$

In addition to those shown above, consonant deletion with C1 target can be found in Akan (Lombardi 2001, citing Schachter and Fromkin 1968), Axininca person prefixes (Lombardi 2001, citing Payne 1981), Carib (Gildea 1995), and Tunica (Wilson 2001, citing Haas 1946).

Consequently, as summarized below, the cross-linguistic generalization which is common to the three phonological processes (voicing assimilation, place assimilation and consonant deletion) is that $\mathrm{C} 1$, in intervocalic C1C2 clusters, is the target whereas C2 is the trigger.

(5) The C2 dominance effect in voicing assimilation, place assimilation, and consonant deletion In intervocalic C1C2 clusters, C1 is a typical target, and C2 is a typical trigger.

Let us consider how to capture this C2 dominance effect. It is not difficult to derive patterns with the C2 dominance effect within the framework of previous theories such as classical generative theory, autosegmental phonology and underspecification theory. For instance, regressive assimilation can easily be characterized by a rule of the type shown in (6a). However, progressive assimilation can also be formulated with equal complexity, as shown in (6b), and its absence, at best rarity, in the typology would be a surprise. Representational theories such as autosegmental phonology, feature geometry and underspecification theory would be no better in this respect than classical generative theory as there is no plausible reason to differentiate in the complexity of the representation between the two members of a consonant cluster. (See Jun (1995) for the relevant discussion.) 
(6) Rules for consonant place assimilation
a. $\quad \mathrm{C} \rightarrow[\alpha$ place $] / \ldots$ [C, oplace $]$
(regressive assimilation)
b. $\quad \mathrm{C} \rightarrow[$ [place $]$ / [C, aplace] _
(progressive assimilation)

Compared to the rule-based theories with a focus on the correct formulation of the language-specific phonological processes, Optimality Theory (Prince \& Smolensky 1993/2004; McCarthy \& Prince 1995) is more concerned with universal patterns, thus being in a better position to explain positional effects such as the $\mathrm{C} 2$ dominance effect and understand the motivation behind processes showing the effect.

Along with the development of Optimality Theory, there have been two major lines of approach to the analysis of the positional effects, Licensing-by-cue and Licensing-by-prosody (in Steriade's (1997/1999) terminology). The Prosody-based approach explains positional asymmetries by reference to prosodic structure. It attributes the C2 dominance effect to the coda-onset asymmetry since C1 and C2 are usually syllabified as a coda and an onset, respectively. The C1 in the coda is likely to be targeted in the processes since the coda is phonologically non-prominent and marked. In contrast, the C2 in the onset resists these processes since the onset is phonologically prominent and unmarked. For an analysis of the empirical data of the C2 dominance effect, either greater faithfulness to the onset and/or dispreference for the coda or (marked) properties in the coda have been called on. Specifically, within the framework of Optimality Theory, positional faithfulness constraints for the onset or/and positional markedness constraints for the coda have been adopted in the literature. (See Casali $(1996,1997)$ and Beckman (1998) for positional faithfulness analyses, and see Zoll (1998) for the comparison between positional faithfulness and positional markedness.)

In contrast, the Cue-based approach (Steriade 1995, 1997/1999, 2001, 2009; Flemming 1995; Boersma 1998; Côté 2000; Wilson 2001; Blevins 2003; Jun 2004) explains the C2 dominance effect by relying on the perceptual factors involved. The $\mathrm{C} 1$ has low perceptibility since it is preconsonantal and thus may lack important perception cues, such as release bursts and C-to- $\mathrm{V}$ formant transitions, to laryngeal/place features and segmenthood under the overlap with C2 (Lamontagne 1993; Wright 1996). In contrast, the C2 is perceptually prominent since it is prevocalic, being able to maintain such perception cues. (See Wright (2004) for a detailed discussion of perception cues.) From the assumption that change in perceptually prominent positions would cause drastic input-output difference, thus being much dispreferred, whereas the comparable change in non-prominent positions would cause less difference, thus being less dispreferred, it is derived that non-prominent C1 is more likely to be modified, i.e., targeted in phonological processes, than prominent C2. Thus, the Cue-based approach attributes the C2 dominance effect to higher perceptibility of C2 over C1.

The two approaches under consideration differ in whether the constraints (and rules) adopted to explain positional effects should be expressed as prosody-based or string-based (more precisely, cuebased) statements. However, the empirical data presented thus far will not distinguish the two approaches, 
since the preconsonantal $\mathrm{C} 1$ which is expected to be the target of the phonological processes in the Cuebased approach is normally syllabified as a coda which the Prosody-based approach also expects to be the more likely target. In sections 4-5, I will present the data patterns for which the two approaches make distinct predictions. 


\section{Non-assimilatory neutralization}

Assimilation can be considered as a case of contrast neutralization. As shown in the previous section, assimilation is primarily regressive (i.e., C1 is the target), and thus potential contrasts of the assimilating feature are neutralized in $\mathrm{C} 1$ position. For instance, in regressive voicing assimilation, consonants in C1 with distinct voice feature values in their underlying form would have identical phonetic realization with respect to voicing, i.e., they are voiced before a voiced segment and voiceless before a voiceless one. Non-assimilatory neutralization of voicing, as well as other laryngeal features, and place of articulation features also targets the C1 and word-final position. In languages which have voicing assimilation in consonant clusters, the word-final position is the only available target of non-assimilatory neutralization, and in fact languages with voicing assimilation mentioned in the previous section show final devoicing, as in (7) (see also CHAPTER 47: FINAL DEVOICING AND FINAL LARYNGEAL NEUTRALIZATION).

(7) Final devoicing in languages with voicing assimilation

a. Catalan (Beckman 1998, citing Hualde 1992):

\begin{tabular}{|c|c|c|c|c|c|}
\hline \multirow{3}{*}{ i. } & & \multicolumn{2}{|l|}{$-\mathrm{V}$} & \multicolumn{2}{|l|}{-\# } \\
\hline & $/ \mathrm{t} /$ & [gátə] & 'cat (f.)' & [gát] & 'bad (m.)' \\
\hline & $/ \mathrm{k} /$ & [pókə] & 'little (f.)' & [pók] & 'little (m.)’ \\
\hline ii. & /b/ & [Кóßə] & 'wolf (f.)' & [Kóp] & 'wolf (m.)' \\
\hline & /g/ & [әті́уә] & 'friend (f.)' & [əmík] & 'friend (m.)' \\
\hline
\end{tabular}

b. Dutch (Kager 1999)

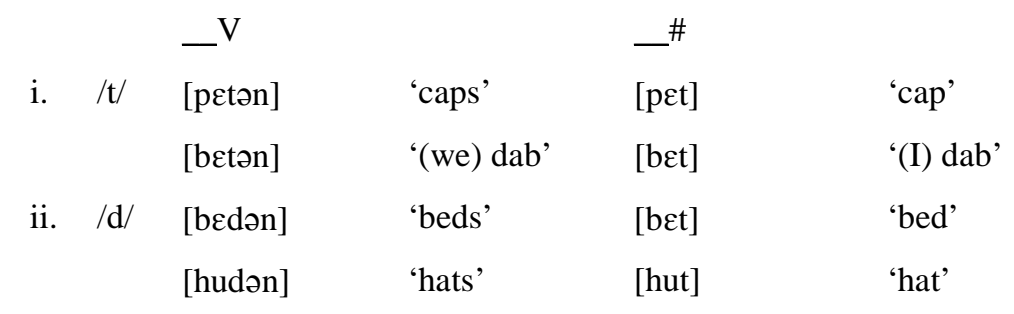

c. Polish (Rubach 1996)

$\begin{array}{lllll} & \mathbf{C}^{\mathrm{V}} & & -^{\#} & \\ / \mathrm{d} / & \mathrm{sa}[\mathrm{d}]-\mathrm{y} & \text { 'orchards' } & \mathrm{sa}[\mathrm{t}] & \text { 'orchards, nom. sg.' } \\ \text { /z/ } & \operatorname{ko[z]-\mathrm {z}} & \text { 'goat' } & \mathrm{kó}[\mathrm{s}] & \text { 'goat, gen. pl.' } \\ \text { /v/ } & \operatorname{pra}[\mathrm{v}]-\mathrm{o} & \text { 'law' } & \operatorname{pra[f]} & \text { 'law, gen. pl.' }\end{array}$

d. Russian (Hayes 1984; Kiparsky 1985; Padgett 2002)

$\begin{array}{lllll} & -\mathrm{V} & & \\ \text { /b/ } & \text { klub-a } & \text { 'club, gen. sg.' } & \text { klup } & \text { 'club' } \\ \text { /d/ } & \text { sa[d]-a } & \text { 'garden, gen. sg.' } & \text { sa[t] } & \text { 'garden, nom. sg.' }\end{array}$


/g/ knig-a 'book, nom. sg.' knik 'book, gen. pl.'

Notice that voiced obstruents may appear before a vowel, more precisely a sonorant, but only neutralized, normally voiceless, obstruents are allowed to occur word-finally in these languages. ${ }^{2}$ In many other languages such as Korean, Maidu, Greek, German, Thai, and Sanskrit, the non-assimilatory neutralization of the laryngeal features such as voicing, aspiration and glottalization occurs not only at the end of the word, but also in preconsonantal C1 position. As mentioned above, Korean has a three-way laryngeal contrast between lenis, aspirated and tense (i.e., glottalized) obstruents. As shown in (8a), the three-way contrast can be maintained before a vowel. However, Korean obstruents are neutralized to their homorganic lenis stop counterparts in the word-final and preconsonantal C1 position (see CHAPTER 121: LARYNGEAL CONTRAST IN KOREAN). As discussed in Lombardi (1995), Maidu also has a three-way contrast between voiceless, implosive and glottalized obstruents. Just like in Korean, the three-way contrast in Maidu is maintained only syllable-initially, i.e., prevocalically, whereas laryngeally marked consonants, i.e., implosive and glottalized ones, occur neither in C1, nor at the end of the word. Some examples of alternations displaying neutralization of glottalized stops are shown in (8b). As discussed in Steriade (1997/1999), Greek has voiceless unaspirated, voiced, and voiceless aspirated stops. The laryngeal distinction among stops can be made before vowels (and sonorant consonants) whereas it is neutralized before obstruents. Some examples of relevant alternations are shown in (8c). Notice that stops in Greek are not allowed to occur word-finally, and thus there is no way to observe active word-final neutralization.

(8) Laryngeal neutralization: target = word-final and pre-consonantal C1

a. Korean

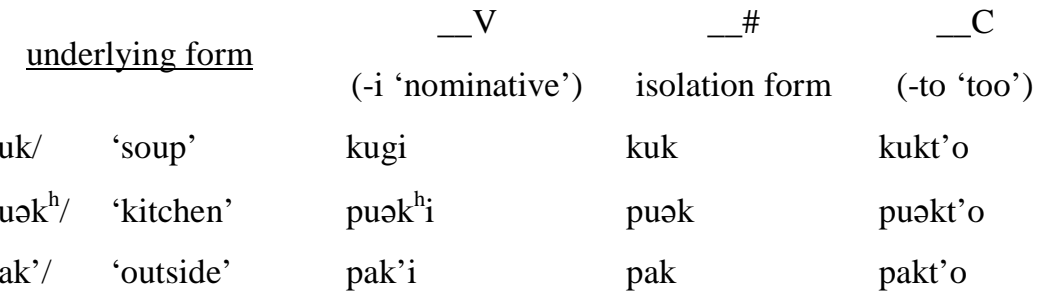

b. Maidu (Lombardi 1995)

\begin{tabular}{cccc} 
& \multicolumn{1}{c}{ p } & $\ldots$ & $-\mathrm{C}$ \\
/pit'/ & 'manure-rolling bettle' & pit & pitk'ololo \\
/jep'/ & jep'im symi & 'defecate, feces' & 'intestines'
\end{tabular}

\footnotetext{
${ }^{2}$ See Steriade (1997/1999) for a discussion of the phonetic realization of the neutralized obstruents and Blevins (2006) for an in-depth discussion of final devoicing and the related survey.
} 
'male’ 'buck deer'

'men'

c. Greek (Steriade 1999)

\begin{tabular}{|c|c|c|c|c|}
\hline & - V & & $-\mathrm{C}$ & \\
\hline i. voiceless & $\mathrm{t}^{\mathrm{h}} \mathrm{o}$ rak-os & 'thorax, gen. sg.' & $\mathrm{t}^{\mathrm{h}}$ orak-si & 'thorax, dat. pl.' \\
\hline ii. voiced & laryng-os & 'larynx, gen. sg.' & larynk-si & 'larynx, dat. pl.' \\
\hline iii. aspirated & trik ${ }^{\mathrm{h}}-\mathrm{os}$ & 'hair, gen. sg.' & $\mathrm{t}^{\mathrm{h}}$ rik-si & 'hair, dat. pl.' \\
\hline
\end{tabular}

In summary, the preconsonantal C1 position is the cross-linguistically common target position of both assimilatory and non-assimilatory laryngeal neutralizations, and the word-final position is additionally the common target position of the non-assimilatory neutralization.

Let us now consider non-assimilatory place neutralization. Just like laryngeal neutralization, place neutralization targets C1 and the word-final position. In languages like Spanish, ancient Greek and Japanese, certain place distinctions are removed through regressive assimilation in clusters, and in a nonassimilatory way at the end of the word. As mentioned in Steriade (2001), in ancient Greek, [n] and [m] in $\mathrm{C} 1$ assimilate in place to the following consonant, and only [n] is allowed to occur at the end of the word. Similar neutralizations can be seen in Spanish and Japanese. In Spanish, there are three nasal phonemes, bilabial, alveolar, and palatal, which are contrastive only in prevocalic position: $\mathrm{ca}[\mathrm{m}] \mathrm{a}, \mathrm{ca}[\mathrm{n}] \mathrm{a}$ and $\mathrm{ca}[\tilde{\mathrm{n}}] \mathrm{a}$ (Harris 1984). In intervocalic C1C2 clusters, place distinctions of nasals in C1 are neutralized since they always agree in place with the following consonant in C2, as shown in (9a.i). Moreover, only a single nasal may occur at the end of the word although dialects differ in the exact place of articulation of the default nasal, i.e., alveolar in standard varieties and velar in non-standard varieties, as shown in (9a.ii, iii). In Japanese, in intervocalic C1C2 clusters, consonants in C1 must agree in place with those in C2, as shown in (9b.i, ii). Thus, within a word, only homorganic nasal and geminate clusters can occur. In addition, the word-final position can be occupied only by a single nasal, which is called the mora nasal and is usually transcribed as [N] or [y]. This nasal is produced with no fixed oral constriction (Vance 1987: 35), and thus it is sometimes argued to be a placeless segment (for instance, McCarthy 2008: 278). (See CHAPTER 20: CONSONANTAL PLACE OF ARTICULATION.)

(9) Place assimilation and final place neutralization

a. Spanish (from Harris 1984)

i. Homorganic NC clusters: ca[mp]o, ma[ns]o, ma[yk]o, á[mf]ora, ma[nt]o

ii. Final [n] in standard varieties: e[n] Chile, ta[n] frîo, u[n] elefante

iii. Final $[\eta]$ in non-standard varieties: $e[\eta]$ Chile, ta[y] frîo, $u[y]$ elefante

b. Japanese (Kager 1999; Yip 1991; Vance 1987; Itô, Mester \& Padgett 1995 ) 
i. Geminates

$\begin{array}{ll}\text { kap.pa } & \text { 'a legendary being' } \\ \text { kit.te } & \text { 'stamp' } \\ \text { gak.koo } & \text { 'school' } \\ \text { Homorganic nasal + obstruent } & \\ \text { tom.bo } & \text { 'dragonfly' } \\ \text { non.do } & \text { 'tranquil' } \\ \text { kan.gae } & \text { 'thought } \\ \text { /yom + te/ } \rightarrow \text { yonde } & \text { 'reading' } \\ \text { /sin }+ \text { te/ } \rightarrow \text { šinde } & \text { 'dying' } \\ \text { Final mora nasal } & \\ \text { hoN } & \text { 'book' } \\ \text { zeN } & \text { 'goodness' }\end{array}$

There are also languages in which place neutralization occurs only in a non-assimilatory fashion. As discussed in Lombardi (2001 citing Rice 1989), nonsonorant consonants in Slave (Athabaskan) are realized as /h/ syllable-finally, as shown in (10a). Sonorants are not different from obstruents in having no place distinctions although the exact final neutralization patterns are not the same. Syllable-final nasals delete, nasalizing the preceding vowel, and /y/ is the only possible coda among non-nasal sonorants. Another example of non-assimilatory place neutralization is from the Kelantan dialect of Malay (Teoh 1988). Final stops /k, t, p/ are realized as [?], and final fricatives like /s/ as [h], as shown in (10b).

(10) Final place neutralization (from Lombardi 2001)

a. Slave

\begin{tabular}{|c|c|c|c|c|c|c|c|}
\hline \multirow{2}{*}{ i. } & /ts'ad/ & ts'ah & 'hat' & ii. & /xaz/ & xah & 'scar' \\
\hline & & -ts'ade & & & & -yaze & \\
\hline ii & /seey/ & seeh & 'saliva' & & /tl'uł/ & tl'uh & 'rope' \\
\hline & & -zeeye & & & & -tl'ułe & \\
\hline
\end{tabular}

b. Kelantan Malay

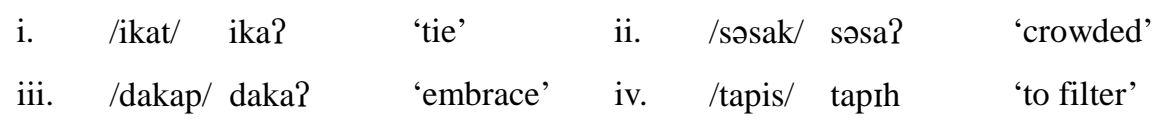

In these languages, contrasts of some features other than place can be maintained finally, for instance, obstruents vs. sonorants in Slave and stops vs. fricatives in Kelantan Malay. But, there are also many languages like Burmese in which all consonants are neutralized to [?]. (See Lombardi (2001) and 
references therein for more details.)

In summary, as stated below, the preconsonantal C1 is not only the typical target of assimilation, but also the typical target of the non-assimilatory neutralization. The word-final position is an additional typical target of the neutralization.

(11) The C2 dominance effect in (assimilatory and non-assimilatory) laryngeal and place neutralization Preconsonantal C1 and word-final positions are common target positions.

It is usually the case that preconsonantal C1 and word-final positions form a natural class, i.e., coda. Thus it is obvious that the Prosody-based approach can provide a unified account of positional neutralizations of $\mathrm{C} 1$ and word-final positions, attributing both cases to the coda-onset asymmetry. The Cue-based approach also provides a somewhat unified account for the two common target positions based on the fact that the word-final position lacks C-to-V transition cues just as preconsonantal C1 does, and thus it has lower perceptibility, compared to the prevocalic C2 position. Consequently, the relatively common positional neutralization patterns presented thus far do not significantly distinguish the two approaches. In the remainder of this chapter, I will consider the patterns which crucially distinguish them. 


\section{Evidence for the Cue-based approach}

\subsection{Neutralization sites $\neq$ syllable positions}

According to the Prosody-based approach, neutralization contexts should be described in prosodic terms: for instance, “codas are the target of laryngeal neutralization.” But, as discussed by Steriade (1997/1999), there are cases in which there is no consistent connection between neutralization sites and syllable structure.

First, there are languages in which neutralization targets only C1, not word-final, positions. Languages in which laryngeal neutralization occurs only in C1, not at the end of the word, include Yiddish, Romanian, Serbo-Croatian (Lombardi 2001: 269), French, Hungarian, and Kolami (Steriade 1997/1999). In addition, place neutralization of nasals occurs only in C1, not at the end of the word, in Diola Fogny (Sapir 1965) and the Souletin dialect of Basque (Hualde 1993). Under the Prosody-based approach, it is not clear why word-medial and final codas behave differently, and even less clear why medial codas are more likely to be targeted in the neutralization than word-final codas (see CHAPTER 35: FINAL CONSONANTS for more discussion). In contrast, in the Cue-based approach, the asymmetry between preconsonantal C1 and final positions may be derived from their relative perceptibility difference. C1 may be considered less perceptible than word-final position because stops in C1, which overlap with consonants in C2, are more likely to be unreleased, thus lacking the release burst and closure duration cues, than those in the word-final position. ${ }^{3}$

Second, laryngeal neutralization targets C1 only before obstruents, not before sonorants, regardless of its syllabic assignment in many languages including Lithuanian, German, Russian, Greek, Sanskrit, Polish, Hungarian and Kolami. Notice that it is possible that C1, in intervocalic C1C2 clusters, is syllabified as a coda when sonorant consonants occupy C2, and then its voicing contrast is expected to be neutralized in the Prosody-based approach. Also, it is usually the case that an obstruent is syllabified as an onset when it occurs as the first constituent of the word-initial clusters composed of obstruents, and then its voicing contrast is expected to be licensed in the Prosody-based approach. These two expectations of the Prosody-based approach are not satisfied in the languages mentioned above. For instance, in Lithuanian where consonant clusters are heterosyllabic regardless of composition (e.g., áuk.le), voicing of obstruents may be contrastive in the coda when they occur before sonorants, as in (12c). The voicing of an obstruent is neutralized in the onset when it precedes another obstruent, as in (12b). Consequently, it is difficult to provide an adequate description of neutralization contexts in syllabic terms.

(12) Lithuanian obstruents in clusters (Steriade 1997/1999)

$$
\text { voiceless } \quad \text { voiced }
$$

\footnotetext{
${ }^{3}$ Blevins (2006: 143) discusses the data from Dhaasana, Chadic Araic, and Maltese in which devoicing occurs exclusively at the end of the word, not in C1 position. This word-final, but not syllable-final, devoicing can be a problem not only for the Prosody-based approach but also for the Cue-based approach.
} 


$\begin{array}{llllr}\text { a. licensed onsets } & \text { samgùs } & \text { 'cheerful' } & \text { žmogùs } & \text { 'man' } \\ \text { b. neutralized onsets } & \text { spalva } & \text { 'color' } & \text { lizdas } & \text { 'nest' } \\ \text { c. licensed codas } & \text { aug.muo } & \text { 'growth’ } & \text { ak.muõ } & \text { 'stone' } \\ \text { d. neutralized codas } & \text { daũ[k] } & \text { 'much' } & & \end{array}$

In contrast, to explain the difference in the likelihood of the neutralization between pre-obstruent vs. pre-sonorant positions, the Cue-based approach may still rely on the perceptibility difference of the two positions. Specifically, the pre-obstruent position lacks the main contextual cues (VOT and other releaserelated cues), and thus is less perceptible than the pre-sonorant position where the main cues can be maintained.

Finally, there are languages in which neutralization patterns are fixed despite the variable syllabification. As discussed by Steriade (1997/1999), for both Sanskrit and Greek, syllable divisions in obstruent-sonorant clusters were variable, depending on "the dialect, the period, the literary style and the juncture separating the consonants”. In contrast, there was no variation in the pattern of laryngeal neutralization: in styles or dialects where VC1.C2V divisions were the norm for all clusters, laryngeal neutralization did not take place before heterosyllabic sonorants. This indicates that laryngeal features in these languages are neutralized irrespective of the syllabic assignment of clusters, and thus the neutralization patterns cannot be adequately described in syllable terms.

The above patterns indicate that syllable positions like codas are neither a sufficient nor a necessary condition for the occurrence of neutralization. Codas are not a sufficient condition in the patterns in which only word-medial, as opposed to final, codas and pre-obstruent, as opposed to pre-sonorant, codas are neutralized. Codas are not a necessary condition in the patterns in which an obstruent onset in word-initial clusters is neutralized. Codas would be totally useless in describing the Sanskrit and Greek patterns with variable syllabification but fixed neutralization patterns. Consequently, all these patterns can be taken as evidence against the Prosody-based approach and in favor of the Cue-based approach.

\subsection{Apical neutralization}

As mentioned above, consonant place assimilation is predominantly regressive across languages. This strong cross-linguistic tendency towards regressive assimilation has been considered a subset case of the C2 dominance effect in place neutralization, as stated in (11) and repeated below as (13).

(13) The C2 dominance effect in (assimilatory and non-assimilatory) laryngeal and place neutralization Preconsonantal C1 and word-final positions are common target positions.

The place neutralization typology displaying this C2 dominance effect provides an important basis for the 
Prosody-based approach's analysis of the coda-onset asymmetry. However, Steriade (2001) notes that this C2 dominance effect in place neutralization is true only when contrasts between labials, alveolars, velars and palatoalveolars (referred to as major C-place contrasts by Steriade) are neutralized. In the case of the neutralization of contrasts between apicoalveolars and retroflexes (referred to as apical contrasts by Steriade), a completely opposite tendency is observed: post-consonantal C2 and word-initial positions are typically targeted. Let us first consider assimilatory neutralization of apical contrasts and then nonassimilatory neutralization.

First, apical assimilation is typically progressive, as can be seen in (14). Notice that in both Sanskrit and Urali, postconsonantal C2 alveolars in the underlying form are realized as retroflexes after postvocalic $\mathrm{C} 1$ retroflexes. Thus, apical assimilation targets $\mathrm{C} 2$, not $\mathrm{C} 1$, which is the opposite of major Cplace assimilation.

(14) (Patterns of word-internal) apical assimilation (Steriade 2001)

a. Sanskrit

\begin{tabular}{|c|c|}
\hline /av-id- ${ }^{\mathrm{h}_{\mathrm{i}}}$ / & [avidd ${ }^{\mathrm{h}} \mathrm{i}$ ] \\
\hline /san-na:m/ & [sanna:m] \\
\hline /jyotiş-su/ & [jyotisssu] \\
\hline
\end{tabular}

b. Urali

/en-nuuru/ [enquuru] 'hundred-8 = 800'

/ked-t-a-l [ketta- $] \quad$ 'spoil-intrans'

This C1 dominance effect in apical assimilation seems as robust as the C2 dominance effect in major Cplace assimilation, although the total number of cases of apical assimilation is relatively small. Based on a typological survey of apical assimilation, Steriade (2001) reached the conclusion that apical assimilation in clusters is predominantly progressive, and there is no exception to it when clusters belong to the same word and the two constituents of the clusters are identical in stricture (e.g., both stops).

Non-assimilatory neutralization of the apical contrast also targets the post-consonantal C2, possibly along with word-initial positions. For instance, in Murinbatra, alveolars and retroflexes contrast in both C1 and word-final position. In contrast, the apical contrast is neutralized in post-consonantal C2. Apicals in C2 are always realized as alveolars after non-apicals, and as homorganic with an apical C1. Thus, the non-assimilatory neutralization of the apical contrast targets C2 in Muringbata. Miriwung is just like Murinnbata in that the apical contrast is maintained in C1, but neutralized in C2. Apical neutralization additionally occurs at the beginning of the word in which only alveolars, not retroflexes, are allowed to occur.

Consequently, the typical targets of apical neutralization may be summarized as below: 
(15) The C1 dominance effect in (assimilatory and non-assimilatory) apical neutralization Postconsonantal C2 and word-initial positions are common target positions.

So, this is completely opposite of the C2 dominance effect in the neutralization patterns of laryngeality and major C-places of articulation. Given that C2 is usually an onset, the Prosody-based approach cannot explain the $\mathrm{C} 1$ dominance effect in apical neutralization in the same way as the $\mathrm{C} 2$ dominance effect summarized in (13). In contrast, in the Cue-based approach, the C1 dominance effect may be derived naturally from the perception fact that cues to the apical distinction lie primarily in the V-to-C, not C-to-V, transitions, and thus $\mathrm{C} 1$ is more prominent in the perception of the apical contrast than C2. As discussed by Steriade (2001) citing Ladefoged \& Maddieson (1986), Dave (1976), Stevens \& Blumstein (1975) and Bhat (1973), the formant transitions into retroflexes in C1 show distinctively low F3, F4 values, compared to those of dentialveolars whereas the transitions out of retroflexes in C2 are not distinct from those of dentialveolars. This acoustic asymmetry originates from the characteristic articulation of retroflexes in which the tongue tip moves forward during the closure and releases from the same constriction location as apicoalveolars.

Consequently, both the C2 dominance effect in major C-place assimilation and the C1 dominance effect in apical assimilation may be derived from the main argument of the Cue-based approach, i.e., the neutralization targets positions which lack prominent perceptual cues to the contrasts in question. Thus, the apical neutralization typology may form very strong evidence for the Cue-based approach by showing a case of contrast-specific neutralization. (See Zhang (2004) discussing the contour tone typology for an additional case of contrast-specific licensing/neutralization.) 


\section{Evidence for the Prosody-based approach}

\subsection{Obstruent-sonorant clusters in Catalan}

The Cue-based approach provides a string-based, not prosody-based, account for positional neutralizations. If two sequences are segmentally identical, and thus not significantly different in perceptibility involved, the Cue-based approach expects the two to behave similarly with respect to neutralization even when they have different prosodic structures. Suppose that in obstruent-sonorant C1C2 clusters, the C1 obstruent may be syllabified as either an onset or a coda depending on the environment. The Cue-based approach expects that the C1 obstruent will behave invariably with respect to positional neutralization, regardless of whether it is an onset or a coda. If, as predicted by the Prosodybased approach, the C1 is licensed when syllabified as an onset, but it is neutralized when syllabified as a coda, it will cause a serious problem to the Cue-based approach. Wheeler (2005) shows that there exists such a pattern in Catalan.

As shown in (16a, b), in Catalan, stops except dentals are contrastive in voicing before liquids as well as glides, and sibilants are contrastive only before glides when the obstruent-sonorant sequences are within a word. However, sibilants are always voiced before liquids, as in (17a), and dentals are always voiced before laterals, as in (17b). There are no word-internal sibilant-liquid and dental-lateral sequences with distinct voicing values. In summary, in Catalan, although the voicing contrast of the C1 obstruents in obstruent-sonorant sequences is, in general, licensed, sibilants and dentals are neutralized in voicing before liquids and laterals, respectively. In the Cue-based approach, it is difficult to explain why some obstruent-sonorant sequences behave differently in voicing neutralization from other obstruent-sonorant sequences. In contrast, Wheeler (2005) argues that all obstruents with contrastive voicing in (16) occur in the onset whereas all with neutralized voicing in (17) occur in the coda. ${ }^{4}$ Thus, the Prosody-based approach may easily describe the voicing neutralization of obstruents in obstruent-sonorant sequences in Catalan.

(16) Contrastive obstruent voicing in Catalan obstruent-sonorant clusters

a. non-sibilant /__liquid, glide

$\underline{\text { Voiceless }}$

$\mathrm{p}$ vs

prou $\quad[$ 'prow

sempre ['sem.prə]

t vs d

\section{$\underline{\text { Voiced }}$}

brou ['brow] 'broth' ['ßrow] sembra ['sem.brə] 'sows'

truita ['truj.tə] 'trout' druida ['druj.ðə] 'druid'

\footnotetext{
${ }^{4}$ Although Wheeler does not provide details of syllabification in Catalan, Blevins (2003: 399), who also argues that voicing neutralization in Catalan occurs syllable-finally, suggests that Catalan syllabification is quite predictable by stating that "Catalan syllabification judgments were entirely consistent across speakers”.
} 


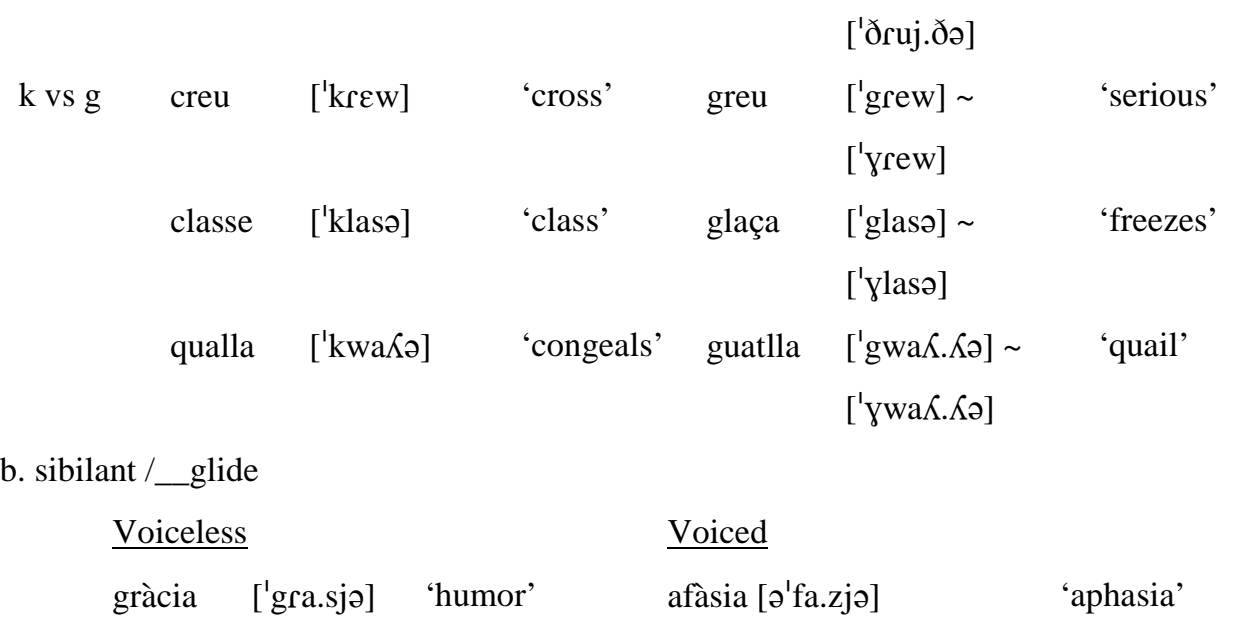

(17) Neutralized obstruent voicing in Catalan obstruent-sonorant clusters

\begin{tabular}{|c|c|c|}
\hline voiced & & voiceless \\
\hline legislar [z.l] & 'to legislate' & None \\
\hline Israel $[\mathrm{z} . \mathrm{r}] \sim[\mathrm{r}]$ & 'Israel' & \\
\hline b. dental /_lateral & & \\
\hline voiced & & voiceless \\
\hline
\end{tabular}

Further, comparable active neutralization, which is even more difficult to explain within the Cuebased approach, can be observed in the obstruent-sonorant sequences occurring across word boundaries. In Catalan, word-final obstruents assimilate in voicing to the following consonants including liquids. Word-final stops, which appear voiceless before an initial vowel of the following word (18ii), become voiced before an initial sonorant (18i). Thus, the C1 obstruents here are neutralized with respect to voicing. This final obstruent neutralization would be never expected within the Cue-based approach since the same obstruent-sonorant sequences within a word are not subject to the voicing neutralization, as shown in (16a). So, this is the case in which identical sequences behave differently with respect to neutralization depending on where they occur. According to Wheeler (2005), the only difference between the obstruent-sonorant sequences of (16a) and (18i) is in syllabic assignment: the C1 obstruents in (16a) are onsets whereas those in (18i) are codas. Thus, only the Prosody-based, not Cue-based, approaches can explain the voicing patterns of obstruents in Catalan.

(18) Neutralized obstruent voicing in Catalan obstruent \# sonorant clusters

a. non-sibilant/_\#liquid
i. poc logic /'pok\#'lozik/
['pog.'lozik]
'not very logical'
ii. poc amable
['po.kə'mab.blə]
'not very friendly' 
b. non-sibilant /_\#glide
i. poc whisky /'pok\#'wiski/
['pog.' wiski]
'not much whisky'
ii. poc usual
['po.ku'zwal]
'not very usual'

\subsection{Obstruent-sonorant clusters in Eastern Andalusian Spanish}

Eastern Andalusian Spanish shows an additional case in which sequences with similar perception cues behave differently in contrast distribution and neutralizing processes, thus posing a problem to the Cuebased approach. The discussion of this section is mostly based on Gerfen (2001).

As shown in (19), in Standard Peninsular Spanish, /s/ is allowed in preconsonantal and word-final positions. In contrast, in Eastern Andalusian Spanish, /s/ is not allowed to occur in those positions. As shown in (20a), word-final /s/ deletes and aspirates the preceding vowel. Preconsonantal C1 /s/ also deletes but the deletion is accompanied by the gemination of the following C2 consonant.

(19) /s/ in Standard Peninsular Spanish (Gerfen 2001)
a. word-final coda:
[ga.fas] 'eyeglasses'
b. pre-C coda:
[gas.ko] 'helmet'

(20) /s/ in Eastern Andalusian Spanish (Gerfen 2001)

a. word-final coda

/ganas/ [ga.na' ${ }^{\text {h }}$ 'desire'

b. pre-C coda
SPS
EAS
i. [bos.ke]
[bo'k.ke]
'forest'
ii. [es.la.ßo] [e $\quad$ e l.la.ßo]
'Slavic'

The Prosody-based approach may easily attribute these distributional restrictions of /s/ in Eastern Andalusian Spanish to a syllable coda restriction. In contrast, the Licensing-by-cue approach may adopt a string-based statement that /s/ is allowed to occur only before a vowel in Eastern Andalusian Spanish. But, as argued by Gerfen (2001), this is hard to justify since sibilants such as /s/ have very salient internal cues in the frication noise, and thus C-to-V transition cues would not be important in the perception of the presence or absence of /s/, unlike in the perception of laryngeal and place contrasts. Thus, there is no plausible phonetic motivation for such a string-based requirement, i.e., that a vowel must be present immediately after /s/, within the Cue-based approach.

Gerfen discusses two more related patterns which are even more problematic for the Cue-based approach. In Eastern Andalusian Spanish, the C1 coda deletion (followed by the gemination of C2) is not 
limited to /s/, but to all obstruents, as shown in (21).

(21) Aspiration of all obstruent codas in Eastern Andalusian Spanish (Gerfen 2001)

\begin{tabular}{|c|c|c|}
\hline SPS & EAS & \\
\hline [ap.to] & [a $\mathrm{a}^{\mathrm{h}}$.to] & 'apt' \\
\hline 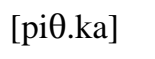 & [pi $\left.{ }^{\mathrm{h}} \mathrm{k} \cdot \mathrm{ka}\right]$ & 'pinch, small amount' \\
\hline [ak.Өjon] & [a $\left.{ }^{\mathrm{h}} \theta . \theta j o n\right]$ ([ahs.sjon]) & ‘action’ \\
\hline b.tu.so] & [o thttu.so] & 'obtuse' \\
\hline
\end{tabular}

Notice that the $\mathrm{C} 1$ obstruents in obstruent-liquid sequences, word-initially or medially, are not subject to this deletion, as shown in (22). In the Prosody-based approach, this difference can be attributed to the coda-onset asymmetry: stop+liquid clusters are syllabified as onsets, thus resisting the coda deletion (see also CHAPTER 39: SC CLUSTERS), whereas obstruent clusters shown in (21) are syllabified as coda-onset sequences, and thus $\mathrm{C} 1$ obstruents in the coda are subject to the deletion. In contrast, to explain the above difference between obstruent-obstruent and stop-liquid sequences, the Cue-based approach would rely on the asymmetry in perceptibility between pre-obstruent and pre-sonorant positions. Specifically, C2 liquids may have richer perceptual cues to the preceding obstruents than C2 obstruents.

(22) stop+liquid clusters in Eastern Andalusian Spanish (Gerfen 2001)

a. Initial stop+liquid clusters
i. [klaro] 'clear'
iii. [plano] 'flat'
ii. [grado] 'grade'
iv. [trapo] 'rag'

b. Word-internal obstruent+liquid clusters
i. [a.klara] 's/he/it clears up'
iii. [a.plana] 's/he/it applies'
ii. [a.grada] 's/he/it pleases'
iv. [a.trapa] 's/he/it traps'

But, then, it is still unclear why /sl/, i.e., an obstruent-liquid sequence, does not behave like stop+liquid sequences. As shown in (20b-ii), /s/ is subject to the coda deletion before /l/. Also, as shown below, /tl/, i.e., a stop-liquid sequence, behaves like /sl/, not like / $/ \mathrm{ll} /$ and $/ \mathrm{gl} /$. If rich perceptual cues to C1 before a liquid can guarantee the intact surface realization of stop-liquid sequences like /kl/, /gr/, /pl/ and /tr/, it is difficult to understand whey /tl/ and /sl/ cannot surface as such.

(23) /tl/ clusters in Eastern Andalusian Spanish (Gerfen 2001)

/atleta/ [a ${ }^{\text {hlleta }} \quad$ 'athlete' 
To summarize, both Catalan and Eastern Andalusian Spanish show asymmetric patterns in which only a subset of obstruent-sonorant sequences is subject to the distributional restrictions and related alternations targeting an obstruent in C1. For the analysis of these patterns, the Prosody-based approach can still attribute the difference among the obstruent-sonorant sequences to the coda-onset asymmetry, but an equally plausible, string-based, solution seems to be unavailable in the Cue-based approach. See Kabak \& Idsardi (2007) for an additional support for the Prosody-based approach, as opposed to Cuebased approach. They have investigated Korean listeners' perception of non-native sequences, and argue that only syllable-based, not string-based, phonotactic constraints can explain their experimental results. 


\section{Conclusion}

From the literature on phonological typology, we know that it is common that phonological processes do not apply in all positions, and more generally that phonological contrasts are not licensed in all positions. Such positional effects are characterized by reference to certain pairs of prominent and non-prominent positions such as word-initial vs. non-initial, stressed vs. unstressed, root vs. affix and prevocalic C2 vs. preconsonantal C1 positions. Among these, this chapter has been mainly concerned with the C2 dominance effect in which preconsonantal C1 in intervocalic C1C2 clusters is likely to be targeted for neutralization whereas prevocalic C2 is likely to trigger or resist such neutralization. This C2 dominance effect is quite robust in laryngeal and place neutralization and consonant deletion. I have looked at the relevant data patterns from well-known and common to less-known and relatively exceptional, while comparing the Cue-based and Prosody-based approaches. Common data patterns can be explained equally well by both approaches. In contrast, less common or somewhat exceptional patterns may distinguish the two approaches. However, the evidence so far is mixed. Not only neutralization patterns in which there is no connection between neutralization sites and syllable positions, but also apical neutralization patterns may form evidence against the Prosody-based approach. In contrast, obstruent-sonorant sequences in which the voicing of C1 obstruent may be licensed or neutralized, arguably depending on syllable structure, may form evidence against the Cue-based approach. Any adequate theory of positional effects, including the C2 dominance effect, should be able to account for all these patterns, common or exceptional. 


\section{References}

Ahn, Sang-Cheol. 1998. An introduction to Korean phonology. Seoul: Hanshin.

Aronoff, Mark \& Richard T. Oehrle (eds.). 1984. Language sound structure. Cambridge: MIT Press.

Bailey, Charles-James N. 1970. Toward specifying constraints on phonological metathesis. LI 1. 347-349.

Baković, Eric. 2001. Nasal place neutralization in Spanish. University of Pennsylvania Working Papers in Linguistics 7.1., http://roa.rutgers.edu, ROA 386.

Barnes, Jonathan. 2006. Strength and weakness at the interface: Positional neutralization in phonetics and phonology (Phonology and Phonetics 10). Berlin \& New York: Mouton de Gruyter.

Beckman, Jill N. 1998. Positional Faithfulness. PhD dissertation, University of Massachusetts, Amherst.

Bhat, D. N. S. 1973. Retroflexion: An areal feature. Working Papers on languages universals, 13. $27-58$.

Blevins, Juliette. 2003. The independent nature of phonotactic constraints: An alternative to syllablebased approaches. In Caroline Fézy \& Ruben van de Vijver (eds.), The syllable in Optimality Theory, 375-403. Cambridge: Cambridge University Press.

Blevins, Juliett. 2006. A theoretical synopsis of Evolutionary Phonology. Theoretical Linguistics 32(2). 117-166.

Boersma, Paul. 1998. Functional phonology: formalizing the interactions between articulatory and perceptual drives. The Hague: Holland Academic Graphics.

Casali, Rod. 1996. Resolving Hiatus. PhD dissertation, UCLA.

Casali, Rod. 1997. Vowel elision in hiatus context: Which vowel goes? Language 73(3). 493-533.

Cho, Young-Mee. Y. 1990. Parameters of consonantal assimilation. PhD disseration, Standford University.

Côté, Marie-Hélène. 2000. Consonant cluster phonotactics: A perceptual approach. PhD dissertation, MIT, distributed by MIT Working Papers in Linguistics, MIT, MA.

Dave, R. (1976) Retroflex and dental consonants in Gujarati: A palatographic and acoustic study. Annual report of the institute of phonetics, University of Copenhagen (ARIPUC), 11, 27-155.

Flemming, Edward. 1995. Auditory representations in phonology. PhD dissertation, University of California, Los Angeles.

Fortescue, Michael. 1980. Affix ordering in West Greenlandic derivational processes. IJAL 46. 259-278.

Gerfen, Chip. 2001. A critical view of licensing by cue: Codas and obstruents in Eastern Andalusian Spanish. In Linda Lombardi (ed.), 183-205.

Gildea, Spike. 1995. A comparative description of syllable reduction in the Cariban language family. IJAL 61. 62-102.

Goldsmith, John. 1990. Autosegmental and metrical phonology. Blackwell.

Haas, Mary. 1946. A grammatical sketch of Tunica. In C. Osgood (ed.), Linguistic structures of native America. New York: Viking Fund. 337-366.

Harris, James. 1980. Spanish Phonology (Research Monograph no. 54). Cambridge, MA: The MIT Press.

Harris, James. 1984. Autosegmental Phonology, Lexical Phonology, and Spanish nasals. In Aronoff \& Oehrle (1984), 67-82.

Hayes, Bruce. 1984. The phonetics and phonology of Russian voicing assimilation. In Aronoff \& Oehrle (1984), 318-328.

Hayes, Bruce. 1986. Assimilation as Spreading in Toba Batak. LI 17. 467-499.

Hayes, Bruce, Robert Kirchner, \& Donca Steriade (eds.). 2004. Phonetically based phonology. Cambridge: Cambridge University Press

Hualde, José. 1987. On Basque Affricates. In WCCFL 6. 77-89.

Hualde, José. 1993. Topics in Souletin Phonology. In José Ignacio Hualde \& Jon Ortiz de Urbina (eds.), Generative Studies in Basque Linguistics, 289-327. Amsterdam: John Benjamin Publishing Company.

Hualde, José. 1992. Catalan. London: Routledge.

Hume, Elizabeth. 1999. The role of perceptibility in consonant/consonant metathesis. WCCFL 17. 293307.

Itô, Junko. 1986. Syllable theory in prosodic phonology. Ph.D. dssertation, University of Massachusetts, Amherst.

Itô, Junko. 1989. A prosodic theory of epenthesis. NLLT 7. 217-259. 
Itô, Junko, Armin Mester \& Jaye Padgett 1995. Licensing and underspecification in Optimality Theory. $L I$ 26. 571-614.

Jun, Jongho. 1995. Perceptual and articulatory factors in place assimilation: An Optimality Theoretic Approach. PhD dissertation, UCLA, Los Angeles, California.

Jun, Jongho. 1996. Place assimilation is not the result of gestural overlap: evidence from Korean and English. Phonology 13. 377-407.

Jun, Jongho. 2002. Positional faithfulness, sympathy and inferred input. MS, Yeungnam University, Daegu, Korea, http://ling.snu.ac.kr/jun.

Jun, Jongho. 2004. Place assimilation. In Bruce Hayes, Robert Kirchner \& Donca Steriade (eds.), 58-86.

Kabak, Baris \& William J. Idsardi. 2007. Perceptual distorions in the adaptation of English consonant clusters: Syllable structure or consonantal contact constraints. Language and Speech 50(1), 2352.

Kager, Rene. 1999. Optimality Theory. Cambridge: Cambridge University Press.

Kenstowicz, Michael. 1994. Phonology in generative grammar. Oxford: Blackwell.

Kim-Renaud, Young-Key. 1974/1991. Korean consonantal phonology. PhD dissertation, University of Hawaii. Seoul: Hanshin.

Kim-Renaud, Young-Key. 1986. Studies in Korean linguistics. Seoul: Hanshin.

Kingston, John \& Mary E. Beckman (eds.). 1990. Papers in Laboratory Phonology I: Between the Grammar and Physics of Speech. Cambridge: Cambridge University Press.

Kiparsky, Paul. 1985. Some Consequences of Lexical Phonology. Phonology Yearbook 2, 85-138.

Kochetov, Alexei \& Marianne Pouplier. 2008. Phonetic variability and grammatical knowledge: an articulatory study of Korean place assimilation. Phonology 25(3). 399-431.

Kohler, Klaus J. 1990. Segmental Reduction in Connected Speech in German: Phonological Facts and Phonetic Explanations. W.J. Hardcastle and A. Marchal (eds.) Speech Production and Speech Modelling, Netherlands: Kluwer. 69-92.

Kohler, Klaus J. 1991a. The Phonetics/Phonology Issue in the Study of Articulatory Reduction. Phonetica 48. 180-92.

Kohler, Klaus J. 1991b. The organization of speech production: clues from the study of reduction processes. Proceedings of the $12^{\text {th }}$ ICPHS. volume 1, 102-106. Aix-en-Provence: Universite de Provence.

Kohler, Klaus J. 1992. Gestural reorganization in connected speech: A Functional Viewpoint on 'Articulatory Phonology'. Phonetica 49. 205-211.

Krueger, John R. 1962. Yakut Manual (Indiana University Publications in Uralic and Altaic Series volume 21). Bloomington: Indiana University.

Ladefoged, Peter \& Ian Maddieson. 1986. Some of the sounds of the world's languages. Working Papers in Phonetics, 64.

Lamontagne, Greg. 1993. Syllabification and consonant cooccurrence conditions. PhD dissertation, University of Massachusetts, Amherst.

Lodge, Ken .1986. Allegro rules in colloquial Thai: Some thought on process phonology. Journal of Linguistics 22. 331-354.

Lodge, Ken. 1992. Assimilation, deletion paths and underspecification. Journal of Linguistics 28. 13-52.

Lombardi, Linda. 1995. Laryngeal neutralization and syllable wellformedness. NLLT 13. 39-74

Lombardi, Linda. 1999. Positional faithfulness and voicing assimilation in Optimality Theory. NLLT 17. 267-302.

Lombardi, Linda. 2001. Why place and voice are different: Constraint-specific alternations in Optimality Theory. In Linda Lombardi (ed.), 13-45.

Lombardi, Linda (ed.). 2001. Segmental Phonology in Optimality Theory: Constraints and representations. Cambridge: Cambridge University Press.

McCarthy, John. 2008. The gradual path to cluster simplification. Phonology 25(2). 271-319.

McCarthy, John \& Alan Prince. 1995. Faithfulness and reduplicative identity. In University of Massachusetts Occasional Papers in Linguistics 18: Papers in Optimality Theory, ed. by Jill Beckman, Laura Walsh Dickey \& Suzanne Urbanczyk, Amherst: GLSA, 249-384.

Mohanan, K. P. 1993. Fields of attraction in phonology. In John Goldsmith (ed.) The last phonological rule: Reflections on constraints and derivations, 61-116. Chicago \& London: The University of Chicago Press. 
Padgett, Jaye. 1995. Partial Class Behavior and Nasal Place Assimilation. http://roa.rutgers.edu, ROA 113. Padgett, Jaye. 2002. Russian Voicing Assimilation, Final Devoicing, and the Problem of [v]. Ms, UCSC. (ROA 528).

Paradis, Carole \& Jean-Francois Prunet (eds.). 1991. Phonetics and phonology: The special status of coronals: Internal and external evidence. Phonetics and Phonology 2, Academic press.

Payne, David L. 1981. The phonology and morphology of Axininca Campa. Austin, TX: summer Institute of Linguistics.

Prince, Alan \& Paul Smolensky. 1993. Optimality Theory: Constraint Interaction in Generative Grammar. Malden, MA: Blackwell. [Originally published as Technical Report CU-CS-696-93, University of Colorado, Boulder, Department of Computer Science, andTechnical Report TR-2, Rutgers University, Rutgers Center for Cognitive Science, new Brunswick, NJ, April 1993.]

Rehg, Kenneth. L. \& Damien G. Sohl. 1981. Ponapean Reference Grammar. Honolulu: The University Press of Hawaii.

Rice, Karen. 1989. A grammar of Slave. Berlin: Mouton de Gruyter.

Rischel, J. 1974. Topics in Greenlandic Phonology. Copenhagen: Akademisk Forlag.

Rubach, Jerzy. 1990. Final devoicing and cyclic syllabification in German. LI 21(1). 79-94.

Rubach, Jerzy. 1996. Nonsyllabic Analysis of Voice Assimilation in Polish. LI 27(1). 69-110.

Sapir, David J. 1965. A Grammar of Diola-Fogny. Cambridge: Cambridge University Press.

Schachter, Paul. \& Victoria Fromkin. 1968. A phonology of Akan: Akuapem, Asante, Fante. UCLA Working Papers in Phonetics 9.

Seo, Misun. 2003. A segment contact account of the patterning of sonorants in consonant clusters. PhD Dissertation, The Ohio State University.

Son, Minjung. 2008. The nature of Korean place assimilation: Gestural overlap and gestural reduction. PhD Dissertation, Yale University.

Son, Minjung, Alexei Kochetov \& Marianne Pouplier. 2007. The role of gestural overlap in perceptual place assiilation in Korean. In Jeffifer Cole \& José Ignacio Hualde (eds.) Laboratory phonology 9. 507-534. Berlin \& New York: Mouton de Gruyter.

Steriade, Donca. 1993. Neutralisation and the Expression of Contrast. Paper presented at NELS 24.

Steriade, Donca. 1995. Positional Neutralization. MS, UCLA.

Steriade, Donca. 1997/1999. Phonetics in Phonology: The case of Laryngeal Neutralization. In M. Gorden (ed.), UCLA Working Papers in Linguistics no. 2: Papers in Phonology 3, 25-146.

Steriade, Donca. 2001. Directional asymmetries in place assimilation: A perceptual account. In B. Hume and K. Johnson (eds.) The role of speech perception in phonology. Academic Press. 219-250.

Steriade, Donca. 2009. The phonology of perceptibility effects: the P-map and its consequences for constraint organization. In Sharon Inkelas \& Kristin Hanson (eds.), The nature of the word: Studies in honor of Paul Kiparsky, 151-179. MIT Press.

Stevens, Kenneth. \& Blumstein, Sheila. 1975. Quantal aspects of consonant production and perception. Journal of Phonetics 3. 215-233.

Teoh, Boon Seong. 1988. Aspects of Malay phonology revisited, A non-linear approach. PhD dissertation, University of Illinois.

Vance, Timothy. 1987. An introduction to Japanese phonology. Cambridge: State University New York Press.

Webb, Charlotte. 1982. A Constraint on Progressive Consonantal Assimilation. Linguistics 20. 309-321.

Wheeler, Max. W. 2005. Voicing contrast: Licensed by prosody or licensed by cue? Paper delivered at the 13th Manchester Phonology Meeting, University of Manchester, 26-28 May, 2005, http://roa.rutgers.edu, ROA 769.

Wilson, Colin. 2001. Consonant cluster neutralization and targeted constraints. Phonology 18. 147-197.

Wright, Richard. 1996. Consonant Clusters and Cue Preservation in Tsou. PhD dissertation, UCLA, Los Angeles, CA.

Wright, Richard. 2004. A review of perceptual cues and cue robustness. In Bruce Hayes, Robert Kirchner, and Donca Steriade (eds.), 34-57.

Yip. Moira. 1991. Coronals, Consonant Clusters, and the Coda Condition. In Paradis \& Prunet (eds.), 6178.

Zhang, Jie. 2004. The role of contrast-specific and language-specific phonetics in contour tone distribution. In Bruce Hayes, Robert Kirchner \& Donca Steriade (eds.), 157-190. 
Zoll, Cheryl. 1998. Positional asymmetries and licensing. MS, MIT, http://roa.rutgers.edu, ROA 282.

\section{JONGHO JUN}

Dept. of Linguistics

Seoul National University

Seoul 151-742, Korea

email: jongho@snu.ac.kr 